\title{
Incidence of Herpesvirus hominis antibodies among blood donor populations
}

\author{
A. P. C. H. ROOME*, D. MONTEFIORE, AND D. WALLER \\ From the Department of Microbiology, Royal Infirmary, Bristol, and the University of Bristol
}

Throughout the world, there has been an increase in the incidence of venereally transmitted infections during recent years (Guthe, 1972), and one such disease, Herpes genitalis, is being diagnosed with increasing frequency (W.H.O., 1974). This infection, due almost entirely to Herpesvirus hominis Type 2 (Amstey, 1973), is important not only because the acute attack is often painful and distressingespecially so in primary infections in women-but also because there is an increasing body of evidence suggestive of a causal link between it and the later development of carcinoma of the uterine cervix (Rapp, 1973).

Both Type 1 and Type 2 viruses are transmitted by close personal contact (Nahmias and Roizman, 1973) and, in the case of Type 2 virus, this usually involves sexual contact. The evidence for this view is based on such findings as the virtual absence of antibodies to Type 2 virus among children below the age of puberty (Nahmias, Josey, Naib, Luce, and Duffey, 1970) and among celibate communities such as nuns (Nahmias and Roizman, 1973), as well as the evidence that the highest incidence of antibodies is found among sexually promiscuous groups such as prostitutes (Duenas, Adam, Melnick, and Rawls, 1972), where it may reach nearly 100 per cent. among the older and longer practising members. In addition, Type 2 virus is isolated from about 90 per cent. of genital herpes lesions (Dowdle, Nahmias, Hartwell, and Pauls, 1967). Antibodies to Type 1 virus do not show this particular age and occupation-linked distribution, although they are more common, and appear at a younger age, among people in the lower socio-economic groups who are likely to live in more crowded conditions than more prosperous members of the community (Smith, Peutherer, and MacCallum, 1967).

Although, in the wild state, the two types of Herpesvirus hominis can generally be readily dis-

Received for publication February 17, 1975

Address for reprints: Dr D. Montefiore, Department of Medical

Microbiology, University College Hospital, Ibadan, Nigeria

$\star$ Present address: Public Health Laboratory, Gloucester tinguished by differences in antigenic composition and in the physical properties of their nucleic acids (Goodheart, Plummer, and Waner, 1968), as well as by differences in such biological properties as the size and type of pock produced on the chorioallantoic membrane of fertile hens' eggs (Parker and Banatvala, 1967), the type of cytopathic effect produced in certain tissue culture cell lines (Smith, Peutherer, and Robertson, 1973), and their neurovirulence for mice, 'intermediate' properties develop readily on passage under laboratory conditions. These intermediate strains also occur rarely in nature, and have been regarded as possibly responsible for occasional 'mixed' types of antibody response (Plummer, 1973).

The identification of the two virus types is a relatively simple matter, but the distinction between Type 1 and Type 2 antibodies in patients' sera is much more difficult, owing to the extensive overlap in antigenic composition which exists between the two types of virus. Various methods have been used to determine the type of herpesvirus antibodies present in human sera, and microneutralization tests have been employed by a number of workers, the results being expressed either as a II/I neutralization index (Rawls, Iwamoto, Adam, and Melnick, 1970) or as pN (Neutralizing Potency) values (Pauls and Dowdle, 1967). This latter method has been used in the present study to determine the frequency of infection by Herpesvirus hominis Type 2 among various blood donor groups, including those from Bath, a largely residential city; Dursley, a small manufacturing town near Bath; and Bristol, a large city; as well as from three different prison communities. One of these comprised largely short-term offenders held under security conditions; another comprised long-term offenders held under security conditions, and the third group were held in an 'open' prison. This latter had a mixed population including an older group serving fairly long-term sentences, and a younger group who had been considered for various reasons to be suitable for detention under low security conditions. 


\section{Methods and material}

\section{(1) Sera tested}

Blood donor sera were obtained from centres in Bristol, Bath, Dursley, Dartmoor Prison, Leyhill Prison, and Gloucester and Horfield prisons. An additional group of sera tested was taken from patients attending the Special Clinic at the Bristol Royal Infirmary because of proven herpes genitalis infections. All the donors from the prison centres were males, and the ages of the prisoners were available except for one group of donors from Horfield and Gloucester prisons: donors from these prisons have been grouped together, as both institutions appeared to cater for the same type of prisoner.

\section{(2) Neutralization tests}

Sera were tested by the microneutralization method, using disposable flat-bottomed plastic tissue culture plates. The titrations of sera were carried out against known fresh isolates of Type 1 and Type 2 Herpesvirus hominis. Control sera obtained from rabbits previously immunized with the respective virus were included in each set of tests. Both the anti-Type 1 and anti-Type 2 rabbit sera were initially tested twelve times against each type of virus, the $\mathrm{pN}$ values determined, and the ratio ' $\mathrm{pN}$ Type 2: $\mathrm{pN}$ Type 1' calculated. This ratio, multiplied by 100 was termed the $\mathrm{NpN}$ value.

The mean $\mathrm{NpN}$ value for each serum was obtained, together with the standard deviation for each set of values. For the Type 1 antiserum a mean $\mathrm{NpN}$ value of 72 was obtained, and for the Type 2 antiserum a mean $\mathrm{NpN}$ value of 94 was obtained, the standard deviations being 3.2 and 4.6 respectively. In testing sera from patients and donors, $\mathrm{NpN}$ values which fell between the mean control values \pm 1 standard deviation were regarded as containing both types of antibody, while those that gave the same or more extreme $\mathrm{NpN}$ values were regarded as containing only a single antibody of the appropriate type.

The method of testing the sera and of calculating the pN values was similar to that of Pauls and Dowdle (1967) with the following variations: The unit volume for reagents was $0.03 \mathrm{ml}$. Neutralization of virus was carried out for $1 \mathrm{hr}$ at room temperature. Vero cell suspensions at a concentration of approximately 750,000 cells per $\mathrm{ml}$. were then added in a volume of $0.03 \mathrm{ml}$., together with a further $0.03 \mathrm{ml}$. of growth medium, making a total of four unit volumes to each well of tissue culture.

Appropriate serum controls, without added virus, and virus back titrations were included in each set of tests, with the volumes adjusted with growth medium to make a total of four unit volumes per tissue culture well in each case.

All reagents were made up in medium containing Eagle's MEM medium with 5 per cent. foetal calf serum plus antibiotics. The buffer system was 0.088 per cent. sodium bicarbonate with $10 \mathrm{mmol}$. HEPES buffer. The plates were incubated in air, without added carbon dioxide, in a humidified incubator for 3 days at $35^{\circ} \mathrm{C}$. before being read.

\section{Results}

\section{(1) Special clinic patients}

Sera from patients attending the Special Clinic for herpes genitalis were examined to confirm that the calculated $\mathrm{NpN}$ values reflected the expected antibody responses in these patients. Each patient tested had been confirmed as having herpes genitalis by isolation of the infecting virus, which was confirmed serologically as Herpesvirus hominis, and also typed on the basis of the cytopathic effect produced in BHK-21 cells (Smith and others, 1973). The results in this series of patients are given in Table $I$.

The type of antibody responses accurately reflected the type of virus isolated from the genital lesions in each instance except in Case 14, where a virus was isolated and identified as a Type 2 strain, while the patient gave a mixed antibody response with the appearance of both Type 1 and Type 2 antibody.

However, the isolated viruses from these patients were also being used for other experiments in mice, and it was reported to us (T. Hill-Personal communication) that this particular virus strain was giving responses in mice more typical of a Type 1 strain than of a Type 2 virus. The tests in BHK-21 cells were repeated, and confirmed as typical of a Type 2 virus. It thus appears that this particular strain was an 'intermediate' type, and was responsible for a mixed antibody response in the patient.

\section{(2) Blood donor sera}

Table II shows the results obtained on 83 sera from blood donors in Bath, classified according to the age group and sex of the donors. The female donors show a significantly higher incidence of Type 1 antibodies than do the male donors: this is evident when all age groups are combined, with the trend being apparent in each age group. As might be expected, the incidence of Type 1 antibodies is significantly $(P<0.05)$ higher in donors over 26 years of age than among the younger donors.

None of the male donors under 25 years old had Type 2 antibodies: these antibodies were detected in only one female donor in this age group. However, there is no significant difference in the incidence of Type 2 antibodies when the two sexes are compared, and the overall incidence is low, being 5 per cent. in males and 7 per cent. in females.

Table III shows similar data for donors from the Bristol area. Again, there is no significant differences between the sexes; although the incidence of Type 2 antibodies appears higher among donors from Bristol than from Bath, with the numbers available, the difference just fails to reach a level of significance at the 5 per cent. probability level.

Table IV shows the results from blood donors from Dursley: in this centre there were few female donors, and hence the sexes are not listed separately. The incidence of Type 2 antibodies is significantly $(\mathbf{P}<0.05)$ higher than among donors from Bath, the increased frequency being largely attributable to the higher incidence of Type 2 antibodies among donors aged 36 years or more. 
TABLE I Antibody response and virus isolation from patients with genital herpes

\begin{tabular}{|c|c|c|c|c|c|}
\hline Case no. & $\begin{array}{l}\text { Age } \\
\text { (yrs) }\end{array}$ & Sex & $\begin{array}{l}\text { Severity of } \\
\text { illness }\end{array}$ & $\begin{array}{l}\text { Known } \\
\text { previous } \\
\text { attacks }\end{array}$ & $\begin{array}{l}\text { Duration before } \\
\text { attendance } \\
\text { (days) }\end{array}$ \\
\hline 1 & 22 & $\mathbf{F}$ & + & + & 1 \\
\hline 2 & 17 & $\mathbf{F}$ & +++ & - & 10 \\
\hline 3 & 25 & $\mathbf{M}$ & ++ & - & 1 \\
\hline 4 & 23 & $\mathbf{F}$ & ++ & - & 3 \\
\hline 5 & 24 & $\mathbf{M}$ & + & - & 28 \\
\hline 6 & 24 & $\mathbf{F}$ & +++ & - & 7 \\
\hline 7 & 21 & $\mathbf{F}$ & + & + & 3 \\
\hline 8 & 23 & $\mathbf{F}$ & ++ & - & 4 \\
\hline 9 & 32 & $\mathbf{M}$ & ++ & - & 4 \\
\hline 10 & 25 & $\mathbf{F}$ & ++ & - & 2 \\
\hline 11 & 20 & $\mathbf{F}$ & ++ & - & 6 \\
\hline 12 & 22 & $\mathbf{F}$ & ++ & - & 2 \\
\hline 13 & 17 & $\mathbf{F}$ & ++ & - & 3 \\
\hline 14 & 23 & $\mathbf{M}$ & + & - & 4 \\
\hline 15 & 38 & $\mathbf{F}$ & + & - & 12 \\
\hline 16 & 21 & $\mathbf{F}$ & + & - & 7 \\
\hline 17 & 38 & $\mathbf{F}$ & ++ & - & 7 \\
\hline
\end{tabular}

Notes (1) Patient 6 had concurrent active Herpes labialis

(2) Virus isolated from Patient 14 gave in vivo Type 1 results (see text)

\begin{tabular}{|c|c|c|}
\hline \multicolumn{2}{|c|}{ Antibody type } & \multirow{2}{*}{$\begin{array}{l}\text { Type of } \\
\text { virus } \\
\text { isolated }\end{array}$} \\
\hline $\begin{array}{l}\text { 1st serum } \\
\text { sample }\end{array}$ & $\begin{array}{l}\text { 2nd serum } \\
\text { sample }\end{array}$ & \\
\hline 2 & NS & 2 \\
\hline 2 & 2 & 2 \\
\hline 2 & NS & 2 \\
\hline $1+2$ & NS & 2 \\
\hline $1+2$ & NS & 2 \\
\hline Nil & 1 & 1 \\
\hline NS & $1+2$ & 2 \\
\hline Nil & 2 & 2 \\
\hline Nil & 2 & 2 \\
\hline NS & 2 & 2 \\
\hline NS & 2 & 2 \\
\hline Nil & 2 & 2 \\
\hline 2 & 2 & 2 \\
\hline Nil & $1+2$ & 2 \\
\hline $1+2$ & $1+2$ & 2 \\
\hline Nil & 2 & 2 \\
\hline 1 & $1+2$ & 2 \\
\hline
\end{tabular}

NS $=$ No serum available

Nil = Antibody titre less than $1: 10$

TABLE II Incidence of antibodies to Herpesvirus hominis 1 and 2 among blood donors in Bath

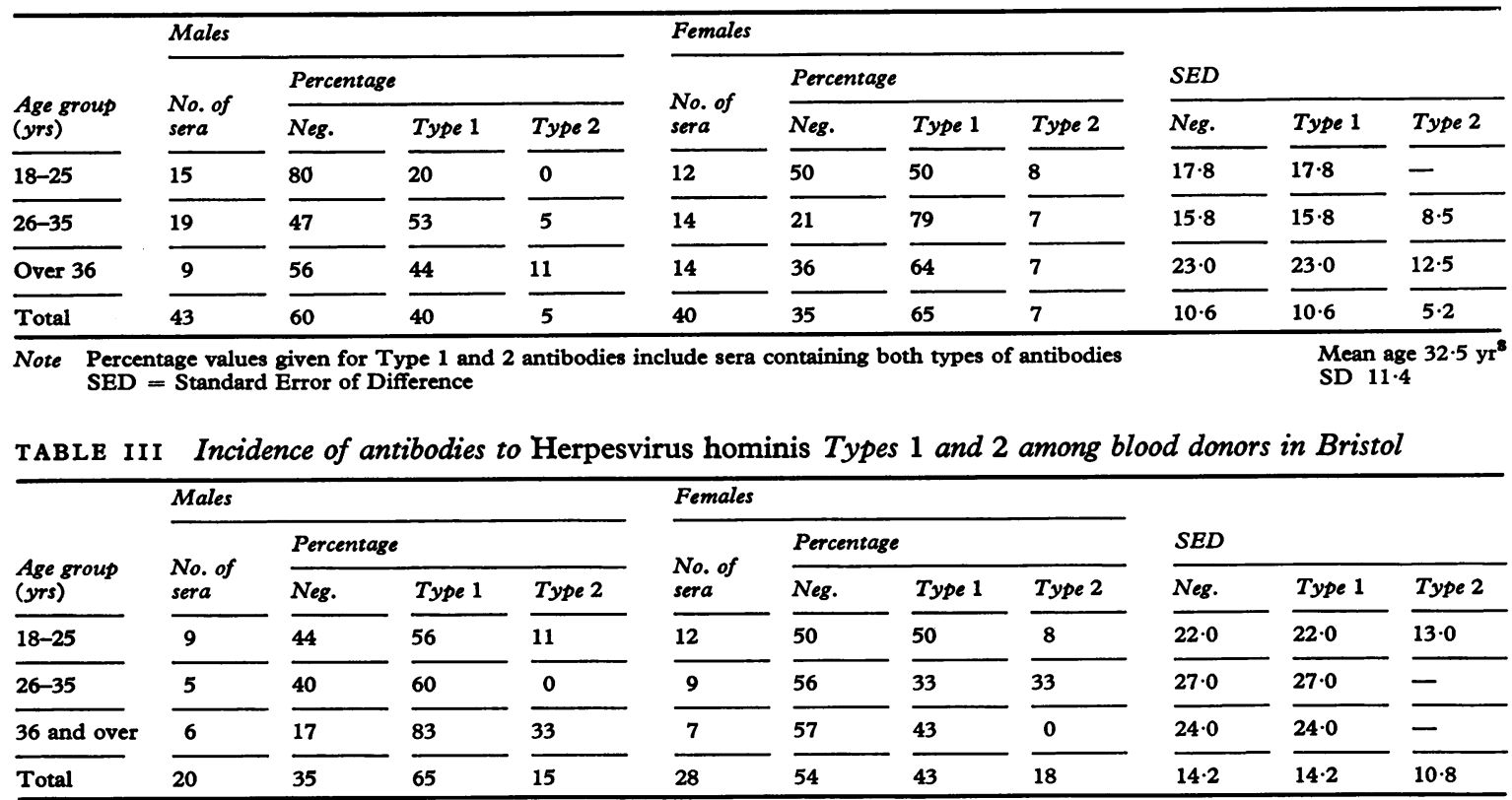

Mean age (all donors) $31.5 \mathrm{yrs}$

SD $11 \cdot 2$ 
TABLE IV Incidence of antibodies to Herpesvirus hominis Types 1 and 2 among 48 male blood donors in Dursley

\begin{tabular}{|c|c|c|c|c|}
\hline \multirow{2}{*}{$\begin{array}{l}\text { Age group } \\
\text { (yrs) }\end{array}$} & \multirow{2}{*}{$\begin{array}{l}\text { No. of } \\
\text { sera }\end{array}$} & \multicolumn{3}{|c|}{ Percentage } \\
\hline & & Neg. & Type 1 & Type 2 \\
\hline $18-25$ & 14 & 67 & 33 & 17 \\
\hline $26-35$ & 16 & 44 & 56 & 13 \\
\hline 36 and over & 18 & 44 & 56 & 28 \\
\hline Total & 48 & 48 & 52 & 19 \\
\hline
\end{tabular}

Mean age 33.0 yrs

SD $11 \cdot 4$

Thus, Bristol and Dursley donors show a very similar incidence of Type 2 antibodies-about 19 per cent. for all ages combined-while the incidence of Type 2 antibodies is around 6 per cent. among donors in Bath.

Table $\mathrm{V}$ lists the data for the three prison groups: it may be noted that the mean age of donors from the Leyhill 'open' prison is higher $(P<0.05)$ than that of donors in the other prisons.

There is a high incidence of antibodies against Type 2 virus among the donors in both Dartmoor and Leyhill prisons, and both show a significantly $(P<0.05)$ higher incidence of antibodies than was found among donors in the Gloucester and Horfield prison group. Similarly, donors in the former two prisons show significantly $(P<0.05)$ higher frequencies of Type 2 antibodies than occur in any of the centres at Bristol, Dursley, or Bath. However, donors in the Gloucester and Horfield prison group do not differ significantly from donors in Bristol and Dursley, although they do show a significantly higher $(P<0.05)$ incidence of Type 2 antibodies than donors from Bath. In the youngest age groups from these prisons, however, there is a significantly higher incidence of Type 2 antibodies than is found among any of the outside donor groups $(P<0.05)$.
Donors in all prison centres show significantly higher incidences of Type 1 antibodies than do donors in any of the outside centres, and significantly fewer of them lack antibodies to either type of virus.

In all instances probability values were calculated from the standard error of the difference between the values being compared.

\section{Discussion}

It is recognized that antibodies to Herpesvirus hominis are more frequent among the lower socio-economic groups, and this appears to be true for both Type 1 and Type 2 antibodies (Nahmias and Roizman, 1973). Previously reported studies from America (Kaufman, Gardner, Rawls, Dixon, and Young, 1973) suggest an incidence of around 10 per cent. for Type 2 antibodies among the higher socioeconomic groups, and this compares closely with the present findings for blood donors in Bath, a largely residential city. The donors in Dursley show a somewhat higher incidence of Type 2 antibodies, being closely similar in this respect to the donors in Bristol. However, the overall incidence, for both sexes combined, is very similar in all three centres with respect to Type 1 antibodies, so it appears likely that the differences in the incidence of Type 2 antibodies reflect differences in sexual behaviour among the donors in the different groups rather than purely socio-economic differences.

The incidence of Type 2 antibodies was significantly higher among the donors from Dartmoor and Leyhill prisons than it was among any of the outside donor groups, and was also significantly higher than the incidence found among the group of donors from Gloucester and Horfield prisons. Indeed, donors in this latter group were almost identical, with regard to the incidence of Type 2 antibodies, to donors in the Dursley and Bristol areas. This could be explained by the fact that since the Gloucester and Horfield

TABLE $\mathrm{V}$ Incidence of antibodies to Herpesvirus hominis Types 1 and 2, among male blood donors in Horfield and Gloucester Prisons, Dartmoor Prison, and Leyhill Prison

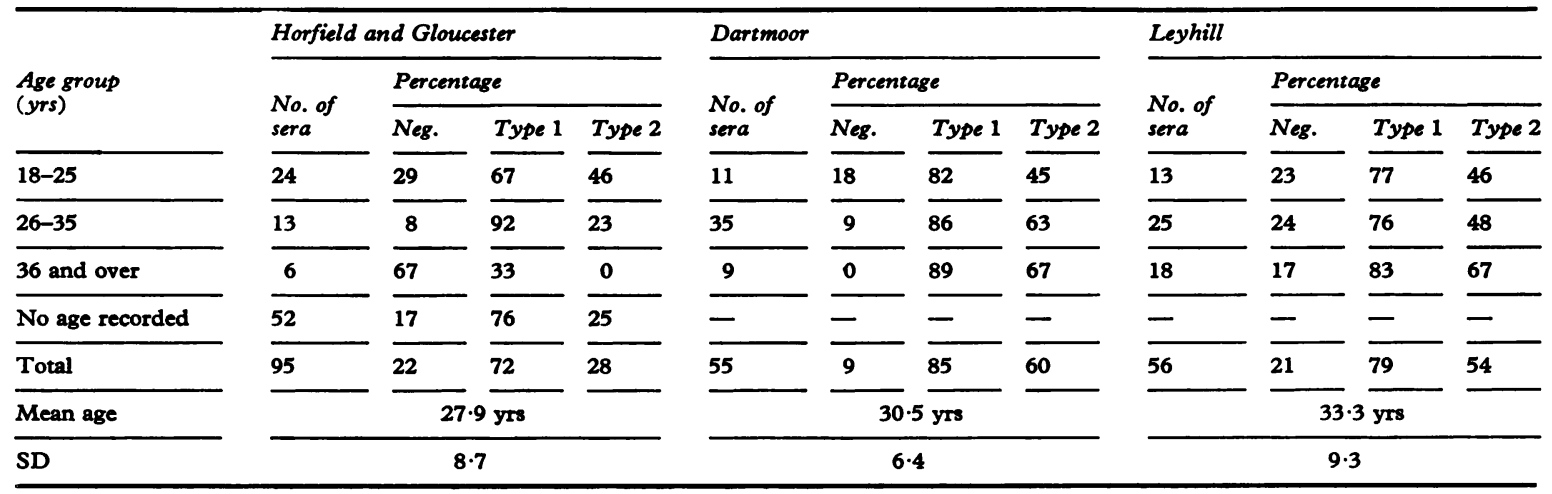


prisons cater for relatively short-term prisoners, the findings among donors in this group might still reflect the findings in their original communities.

However, the incidence of Type 1 antibodies was significantly higher among all prison donors than it was among any of the outside donor groups, explicable either on the grounds that the prison donors came from lower socio-economic groups than did the donors at the outside centres, or on the basis that there may be a ready spread of herpes virus infection in prison. The fact that there is a clear distinction with regard to Type 2 antibodies between the short-term prisons and the long-stay prisons, Leyhill and Dartmoor, is more difficult to ascribe to differences in the socioeconomic background of the donors in these centres, and would suggest that virus can spread within prison.

Both types of herpes viruses are considered to require close personal contact for spread: in the case of Type 1 virus-which causes the so-called 'above the waist' infections-this is thought to be generally non-sexual contact (Selling and Kilbrick, 1964), while in the case of Type 2 virus-the cause of so-called 'below the waist' infections-it is considered to be largely due to sexual contact, although Type 2 virus has been isolated from non-genital sites in the absence of genital lesions, suggesting that nonvenereal spread can occur with this type of virus (Poste, Hawkins, and Thomlinson, 1972).

The evidence of a higher incidence of antibodies among inmates of the longer-stay prisons, when compared not only with the outside population, but also with the donors from the shorter-stay prisons, suggests the possibility that infection can spread under these conditions-fairly rapidly in the case of Type 1 infections, and less rapidly in the case of Type 2 infection. In the case of Type 2 infection, spread could be by homosexual contact as well as by non-sexual contact, either directly or via fomites. Preliminary experiments carried out by us suggest that, under certain conditions of high humidity, Type 2 virus can remain viable on cloth-for example towels-for fairly long periods, thus making transmission of infection by this route a possibility.

\section{Summary}

The microneutralization test was used to determine the occurrence of antibodies to Herpesvirus hominis Type 1 and Type 2 in sera from patients attending the Special Clinic, Bristol Royal Infirmary, with proven herpes genitalis, and in sera taken from blood donors in Bath, Dursley, and Bristol, as well as from donors in three different prison populations.
The findings in patients with herpes genitalis indicate that the test accurately reflects the antibody response expected in relation to the type of herpes virus isolated from the lesions.

The incidence of Type 2 antibodies among the blood donors ranged from 5 per cent. for donors from the Bath area up to 60 per cent. among donors from Dartmoor prison. The findings suggested that Type 2 herpes infection could spread among longterm prison populations, and it is postulated that this may be due to both homosexual contact, and also by non-sexual contact, either directly or via fomites.

We should like to thank Dr Webb, of the South Western Regional Transfusion Service, for kindly supplying samples of serum taken during routine blood donor sessions.

This work was financed in part by a grant from the Medical Research Committee, Bristol Royal Infirmary.

\section{References}

Amstey, M. S. (1973) Amer. F. Obstet. Gynec., 117, 717 Dowdle, W. R., Nahmias, A. J., HaRwell, R. W., and PAuls, F. P. (1967) f. Immunol., 99, 974

Duenas, A., Adam, E., Melnick, J. L., and Rawls, W. E. (1972) Amer. F. Epidemiol., 95, 483

Goodheart, C. R., Plummer, G., and Waner J. L. (1968) Virology, 35, 473

GutHe, T. (1972) Postgrad. med. $f$., 48 January Suppl., p. 7

KaUfMaN, 'R. H., GaRdNER, H. L., Rawls, W. E., Dixon, R. E., and Young, R. L. (1973) Cancer Res., 33, 1446

Nahmias, A. J., Josey, W. E., NaIB, Z. M., Luce, C. F., and Duffey, A. (1970) Amer. F. Epidemiol., 91, 539

and Roizman, B. (1973) New Engl. F. Med., 289, 781

Parker, J. D. J., and Banatvala, J. E. (1967) Brit. f. vener. Dis., 43, 212

Pauls, F. P., and Dowdle, W. R. (1967) F. Immunol., 98, 941

Plummer, G. (1973) Cancer Res., 33, 1469

Poste, G., Hawkins, D. F., and Thomlinson, J. (1972) Obstet. and Gynec., 40, 871

RAPP, F. (1973) f. nat. Cancer Inst., 50, 825

Rawls, W. E., Iwamoto, K., ADam, E., and Melnick, J. L. (1970) f. Immunol., 104, 599

Selling, B., and KIBRICK, S. (1964) New Engl. f. Med., 270, 979

Smith, I. W., Peutherer, J. F., and MacCallum, F. O. (1967) 7. Hyg. (Camb.), 65, 395

- - , and Robertson, D. H. H. (1973) Brit. $\mathcal{F}$. vener. Dis., 49, 385

World Health Organization Wkly Epidem. Rcd, 1974, 42, 352 